\title{
IMPORTANT CONTRIBUTION TO THE CREATION OF THEATRE ENCYCLOPEDIA OF TATARSTAN
}

\author{
Natalya Abramovna Rosenberg, \\ 2 Parkovaya, Vyborg, 188811, Russian Federation, \\ nat-rozenberg@yandex.ru.
}

\begin{abstract}
The review notes the combination of different approaches in the analysis of the Tatar theater scenography (cultural-historical, art history), the use of a wide range of sources, and the painstaking work on the systematization of factual material. In the monograph, the analysis of scenography is presented as a history of the search and struggle for the renewal of the theater at the turn of the era, unique in its complexity, characterized by radical contradictions and the struggle of ideas. The review highlights the significance of the research findings on the national identity of the Tatar theater scenography.
\end{abstract}

Key words: Tatar theater, scenography, national identity, ethno-cultural processes, Orientalism, carnivalization.

Theater artists, stage designers or scenographers, are a very special phenomenon today. They collaborate with theatre directors, creating a spatio-temporal interpretation of the play, based on a dramatic work. It is the synthesis of the word-image-acting of actors-music-lighting that is the overall image of the performance. Art is extremely multifaceted, it being its distinguishing feature.

Due to the visual appeal of this art, stage designers always feel the breath of their viewers and their reaction. They are always in line with artistic trends, social problems, and cultural policies of the state, the subject of the federation, and their city authorities. Often the stage designer's judgment about the success or failure of the production is more accurate than the opinion of a professional critic.

The relatively recent art terminology, defining the work of the stage designer, is the evidence of essential changes in the field of theater art today.

In her study, Rauza Sultanova explores the development of the Tatar theater scenography since its inception, from the beginning of the 20th century to the present time. This is an urgent topic for art history, since the author has no predecessors, and the theatrical life in Tatarstan is distinguished by its diversity and rich repertoire. The Tatar people's cultural traditions go back centuries, and Kazan was and still is the cultural center of the Volga region. The author emphasizes that not only Kazan theaters have their own audiences, but also a number of other cities in Tatarstan have theaters with their loyal viewers.

The monograph includes an appendix of great documentary and artistic value.
The structure of the book is distinguished by its logic, thoroughness, and originality. In her study, R. Sultanova combines the cultural-historical approach, substantiating periodization, and the proper art criticism, when analyzing the works of theater artists. The author's conclusions on the semantics of the national worldview, embodied in art, are theoretically significant.

We note R. Sultanova's painstaking and thorough work on collecting and attributing research material. Her monograph is based on the data from public and private archives, newspaper and journal publications, and recordings of conversations with theatrical figures. While studying scenography, she took on the additional function of finding and often saving theatrical costumes. She collected and systematized posters of performances, unique in beauty and originality of the font graphics. Thus, the comprehensive approach, used in R. Sultanova's research, is very important to fully understand the meaning of theater artists' activities and the atmosphere of theatrical life, to realize the significance of theater in the Tatar people's culture. As early as in the period of its formation, the Tatar theater was a truly people's art. R. Sultanova vividly recreates the very circumstances of its genesis.

The hall of the first mobile theater troupe "Sayyar" (1906-1912) was always packed full and the viewers often provided the necessary props and costumes. The theater democracy led to a dialogue with the audience, which has become a hallmark of the Tatar theater. The outstanding writer-educator G. Kamal was at its origin, now the theater bears his name.

The theatrical and decorative style of the performances in this period is characterized by the au- 
thor as domestic naturalism with features of ethnography. The author notes that in this type of theater, the actors' performance was of predominant importance. It was with the arrival of artist $\mathrm{S}$. Yakhshibaev, invited by G. Kamal, that the static condition of the "interior" theater was overcome in the course of his stationary work. It was then that the scenery recreated specific scenes and the emotional atmosphere was enhanced by the color and special lighting added by the artist. According to the author, the extension of artistic decorative means, to a certain extent, was due to the influence of the Russian theater.

It is quite justified that R. Sultanova devotes a special chapter to the post-revolutionary fifteen years. During those years, Kazan was the largest center of creative experiments, exhibition and museum activities, and art education in all of Russia. Until recently, there have been heated disputes over the importance of the creative heritage of Kazan LEF and SULF, its Tatar section. According to R. Sultanova, theatrical and decorative art of the period under consideration encompassed all the artistic trends of those years - from realism to LEF. Her monograph consistently proves that the achievements of "left" artists were in demand throughout the twentieth century. It is valuable that R. Sultanova traces the continuity between the graphic team "Vsadnik" ("The Horseman"), the ARKHUMAS and the Design and Experimental Workshop of the Modern Theater (KEMST). The forms of mass agitation art in the stage interpretations of their theatrical performances had a constructivist outline. The stage space could be transformed into multi-level platforms, and the costumes and plastic of the actors acquired pointygraphic forms. A successful example of the KEMST production was the "Mystery Buff" by V. Mayakovsky, whose work inspired many Lefovites. The author introduces into scientific circulation and discusses a number of KEMST productions, especially their scenography. In this way, the collaboration of artist K. Chebotarev and young director R. Ishmuratov was successful.

A significant contribution to the theatrical and decorative art was made by P. Benkov, a painter of the older generation (1872-1949). He was the first professional artist of the Tatar theater. His work, as the author believes, combined the traditions of the Moscow Art Theater with a tendency toward picturesque scenery and the national principle of decorativeness, festivity and brightness of color, the pursuit of a spectacular performance. This was fully manifested in the productions of the national drama - the romantic tragedy "Tahir and Zukhra" by F. Burnash (1921) and other dramatic works, such as "The Lost Girl" (1927) and "Husain Mirza" (1927) by F. Burnash, "Beyond the Walls of Old Kazan" by M. Zaitov.

B. Urmanche, a classic of Tatar art (18971990), was also engaged in theatrical activities at the start of his career.

The 1930s and 1950s were the most difficult years for the Tatar theater, when the main criterion for art was the communist party ideology, hence its socialist content. The national form was perceived as something secondary. Let us not forget that one of the main tasks of the Cultural Revolution was the struggle against religious views and traditions, whether it be Islam, Christianity, or paganism. Traditions and rituals that had developed over the centuries forming the basis of everyday and festive lifestyles were eradicated. Consequently, the content of folklore and literary works was subjected to merciless reduction. In this situation, the leading place was occupied by heroic-revolutionary performances about the renovation of everyday life.

As Sultanova shows in her monograph, the fate of the literary works and their authors was often in the hands of poorly educated officials from the administration and party leadership, like in the case of M. Abdullin, an artist of the Tatar Academic Theater. The most inauspicious period was from 1936 to 1945 , when prominent figures of national culture were subjected to repression, and the censorship was severe. K. Tinchurin, one of the founders of the Tatar theater, was repressed and executed, and B. Urmanche was exiled for many decades. Even after his return to Kazan in 1958, the authorities continued to be very wary of his work in the theater, as a result, he did much less than he could have. Benkov had to leave Kazan against his will, and continued his work in Uzbekistan, B. Urmanche lived in Central Asia from 1941 to 1958 .

In that period, P. Speransky (1891-1969), who belonged to the Old Kazan School worked miracles of creative invention and ingenuity. From 1924 to 1969 , he was the leading artist of the Kazan Bolshoi Drama Theater, later the Tatar Academic Theater, for almost a quarter of a century he worked as the chief artist of the Tatar Opera and Ballet Theater named after M. Jalil. The author emphasizes that for all his unstoppable imagination and desire to make his performance spectacular, Speransky carefully studied Tatar folk art in museum collections and expeditions. Therefore, in his productions of national classical works (G. Kamal, 
T. Gizzat, N. Isanbet) he closely adhered to the facts, and creating the costumes of characters, he knew perfectly well the interior of the Tatar house.

According to R. Sultanova, his scenography of the performances, based on the Turkic epos "Idegas" and the play "Khoja Nasretdin", is distinguished by individual perception of the artistic heritage. During his career, P. Speransky created the scenography of 63 performances, remaining a subtle stylist, an expert in culture and art of different eras and peoples. It should be noted that he used a lot from various sources. Thus, the color scheme of his landscape backdrops resembled the "Mir iskusstva" (World of Art) style of painting, the works by Golovin and Benoit. Performances on revolutionary topics were based on the experience of KEMST. Speransky showed himself as an outstanding theater figure. In 1952, at the Conference of Theater Artists of the TASSR, he named the causes of the theatrical art crisis in the Republic. The artist noted that it was the problem caused by planned economy and the state of criticism, which had led to a decrease in the ideological and artistic quality of performances. It is significant that a decision was made to improve the quality of performances with the help of guest directors. The author highly appreciates the results of the collaboration of V. Bebutov, a director, and P. Speransky on the productions of Russian and European classics. "King Lear" successfully ran in Moscow and was interpreted not so much as a realistic work, but as a work combining the features of modernity and medieval aesthetics. This unexpected interpretation of the famous tragedy gave rise to a lively debate in the press.

Innovative solutions did not immediately win through in the Tatar theater. The notorious social demand hindered creative searches for decades. Therefore, R. Sultanova seeks to show the formation of scenography proper as a result of the interactions between the director and the artist. Only in the 1960s and 1970s, it was possible to speak about the new function of the artist as a co-author of the play, and, as follows from the presentation logic, P. Speransky most consistently moved in this direction. In the monograph, it was $M$. Salimzhanov (1936-2002), the head director of the Tatar State Academic Theater (TSAT) named after G. Kamal, who was the renovator of the Tatar theater, who created a conditionally metaphorical, acting theater. In the director's productions the object-spatial environment acquired a symbolic meaning. Salimzhanov's searches took place in line with the renewal of the Russian theater in
Moscow and Leningrad / Petersburg. We mean creative searches of D. Borovsky and E. Kochergin. At that time, the actors of the TSAT were mainly graduates of metropolitan universities. More than once, Salimzhanov had to defend his vision of dramatic material in front of the theater administration and art critics. The director was not afraid to address topical social issues.

The detailed episode, devoted to the preparation of the play "Three Arshins of Land" based on the novel by A. Gilyazov, makes a strong impression. The ban on showing the play, which was completely ready, was a difficult trial for the theater in 1974. However, it was possible to revive this performance in 1987. The author notes that the play became the hallmark of the theater on its tour in Leningrad in 1989. At this time, of predominant value in the repertoire of theaters, as well as in the works of writers and artists, were the works about modern times, while productions about revolutionary transformations in the country gave way to historical ones. Dramatic changes took place in the national consciousness itself, which evidenced the people's strive for ethnocultural self-identification, for regaining their roots. People were clearly attracted by heroic and epic genres of folklore. Experts were increasingly often looking back at the achievements of Tatar art in the 1920s, manifesting their desire to establish the connection between the eras of the 1920s and 1970s. We should note that while studying the ethnocultural processes in the self-consciousness of the peoples from Russia in the late 1970s, K. Chistov, a well-known ethnographer of our country, concluded that the ethnic element was moving from the realm of material culture, ritual life, and even the language into the spheres of national professional culture, ethnopsychology and, to a certain extent, folklore [Chistov]. The reconstruction of the axiological aspects of consciousness with varying degrees of intensity took place in various fields of creativity. The theater with its active position and direct connection with the audience became a vivid exponent of the changed values.

In his research, the author does not provide any extensive historical and cultural introduction into this problem. Being a researcher in the national theater scenography, she finds it symptomatic that due to the cultural policy of the 1980s, in the TASSR, the publications in Tatar were banned and persecuted, the number of publications and Tatar schools decreased, as a result, the theater audience could be lost. She refers directly to the repertoire of the TSAT named after Kamal and, analyzing 
this material, writes about the preservation of ethnocultural identity in the 1960s-1990s. If the spectators' favorite melodrama "The Blue Shawl" by K. Tinchurin with its wonderful female characters and unique scenes of national life is included in the updated repertoire as a classic of the Tatar theater, the play "Idege", directed by M. Salimzhanov (set designer T. Enikeev), presents a new interpretation of the heroic dastan. Its events are understood as a cataclysm, whose significance goes far beyond the scope of feudal strife. The scenery recreates this infinite space of the tragedy, which unfolded long ago. This performance has become the evidence of our awareness that Tatar cultural heritage is a component of Eurasian culture.

A typical example of a scenographer's work in a national theater is the work of S. Skomorokhov. Without being a Tatar and without being connected with the Kazan tradition, he managed to use the experience, gained in other theaters of the Volga cities, to enhance the collaboration between the director, the set designer, and the actors. The author notes that Skomorokhov felt at ease both as a scenographer of plays by European authors and Tatar theater classics. Skomorokhov understood the distinguishing features of the Tatar theater style, which, according to the researcher, enabled him to create performances that had style integrity. Together with the director, the stage designer was ready to go on the most daring experiments, even with regard to national classics. Thus, in the famous "Shurale" by G. Tukay semantic accents were rearranged. Forest evil spirits were transformed into pre-revolutionary intellectuals, wandering in a thicket of trees, dressed in exquisite white costumes.

It is quite obvious that the Tatar theater developed in line with the postmodern searches. The final chapter of the monograph is entitled "The Diversity of the Art Language - the Scenography of 1990-2010". The author writes that during this period a new, effective scenography emerged when " $<\ldots>$ the spatial environment determines interactions between all components of a theatrical performance" (p. 458). This performance may discourage the audience by its Sots-Art postmodern approach to the realities of modern life as it happened in the case of the play "Divana" ("The Obsessed" by T. Minnullin, director F. Bikchantaev, stage designer T. Enikeev). The behavior of Ville, the main character of the play, who imitates the leader of the world revolution in everything, seems to be on the verge of absurdity in the time of mode rn reality. Parodying the protagonist's behavior, which is not quite adequate, the scenographer reproduces Lenin's attributes of life in his realities: a hut becomes his dwelling, his clothes and hairstyle resemble his idol's. Thus, the Soviet myth about the great leader is subject to deconstruction, followed by the myth about the blazed path, in the same way as it happened in the play "The Basketball Player" (2001). The scenographer organizes the grotesque space, the grotesque sports field, the costumes and plastic of the characters themselves, who believe that, after achieving unprecedented success in sports, they will be able to change the surrounding life as a whole.

The author believes that this mixing of genres and the striving for vivid visual appeal and entertainment in the performances is due to the influence of mass culture, which is inevitable in modern conditions. We can add that the theater's interest in the youth audience is also of importance in this case. In this context, especially significant are R. Sultanova's conclusions concerning the preservation and transformation of Oriental traditions in the modern Tatar theater. As early as at its origin, it gravitated towards brightness and decorativeness in the costumes of characters, the features of utensils, and the use of decorative draperies in the spatial environment of the stage. Its tendency to carnivalization, transformation, and character redressing, which was characteristic of the dramaturgy of G. Kamal, one of the founders of the Tatar theater, all these turned out to be quite relevant. R. Sultanova concludes that either the interior or the carnival-game type of scenography prevailed in different periods of the Tatar theater development. In each type of scenography, we feel obvious world exploration archetypically characteristic of national plastic thinking, similar to fingering. Only the space focus is somewhat different. It is objectively outlined in the interior type and variable in the carnival-game type [p. 386]. Here the author shares the ideas of philosopher E. Sintsov about the nature of the non-pictorial in the art of Islam. The figurative-semantic tradition of Islamic art is inherited in the scenography of the TSAT in the symbolism of blue, green and white colors, dominating in the climax scenes. These colors may prevail in the actors' clothing, drapes, and backstage designs. Hence, white dominates in the scenes of ritual actions. In the scenography of national classics performances, one can trace the influence of the Persian miniature with its festivity and color sophistication, with the motif of the Garden of Eden, the multicolor of clothes, and the two- 
dimensional space. The performance, based on the play "The Legend of Love" by Nazim Hikmet, staged in many countries of the world, was very successful. It is obvious that today the issue of the influence that Islam as a faith and attitude exerts on the art of Tatarstan remains significant and needs a comprehensive study.

R. Sultanova discusses the topic of foreign dramaturgy in the Tatar theater and describes the specifics of the perception of B. Brecht's plays. Comparing the productions in Russian and Tatar theaters, she mentions different ways of Brecht heritage acquisition by the Russian and Tatar theaters: in the productions of the Russian theater, the theatrical aesthetics of the German playwright is associated with a systemic renovation of the theatrical art principles. This is a breakthrough into the future, a rejection of the customary psychological theater traditions. In this regard, the path of the Russian theater coincides with the global trend. While in the Tatar theater, Brecht is perceived as part of a cultural space, its elements can be introduced into a play, which is generally oriented towards an already existing tradition. These new elements of the Brechtian system are intended to supplement, enrich, somewhat modify what has already been accumulated and fixed in the theatrical consciousness. In this case, Brecht's innovations are attributed through the well-known elements through the epic spirit, which has always been inherent in the Tatar culture, Tatar verbal art, especially in its ancient forms (legends, legends, bayts, etc.). The epos has always been a part of the Tatars' theatrical culture, therefore in this context, the Brechtian heritage does not appear as something "foreign" and radically new. It is consistent with the ancient tradition, looks like its continuation ... therefore the production of Brecht's plays on the Tatar stage does not mean a rejection of the psychological drama traditions, giving rise to a very curious fusion of two opposite lines of world dramaturgy, which Brecht himself did not imply [p. 514].

At the turn of the 20th -19 th centuries, the TSAT's repertoire included plays by Calderon, Moliere, and Shakespeare. The success of these performances is largely the result of a new quality collaboration between the director, actors, the stage designer, and the more sophisticated viewing audience.

Conclusions summarize the results of the study. The bibliography is distinguished by its completeness of information on the history and theoretical aspects of the stated problems. The practical application of the research results and materials in the Appendices can be very diverse both for the studies of art history, for the theory and practice of theater studies, and for museum work used to create the Theater Museum in the Republic of Tatarstan, whose exposition can be of interest for different categories of visitors.

\section{References}

Chistov, K. V. (1975). Traditsionnye $i$ vtorichnye formy kul'tury [Traditional and Secondary Forms of Culture]. Rasy i narody: Sovremennye etnicheskie i rasovye problem. AN SSSR. In-t etnografii im. N. N. Miklukho-Maklaia. Vyp. 5, pp. 32-41. Moscow. (In Russian)

\title{
ВАЖНЫЙ ВКЛАД В СОЗДАНИЕ ТЕАТРАЛЬНОЙ ЭНЦИКЛОПЕДИИ ТАТАРСТАНА
}

Наталья Абрамовна Розенберг, Россия, 18811, Выборг, ул. Парковая, д. 2, nat-rozenberg@yandex.ru.

\begin{abstract}
Автор отмечает сочетание различных подходов в анализе сценографии татарского театра (культурно-исторического, искусствоведческого), использование большого круга источников, кропотливую работу по систематизации фактического материала. В монографии анализ сценографии представлен как история поисков и борьбы за обновление театра рубежа эпохи, уникальной по своей сложности, остроте своих противоречий и борьбы идей. В рецензии подчеркивается значимость выводов исследования о национальном своеобразии сценографии татарского театра.
\end{abstract}

Ключевые слова: татарский театр, сценография, национальное своеобразие, этнокультурные процессы, ориентализм, карнавализация. 
Художник театра, сценограф - совершенно особое явление в наши дни. Он вместе с режиссером создает пространственно-временную интерпретацию спектакля, беря за основу драматургическое произведение. Синтез словаизображения-игры актеров-музыки-света и есть образ спектакля. Искусство чрезвычайно многогранное, и в этом его особенность.

Зрелищность этого искусства обусловило то, что сценограф всегда чувствует дыхание зала, реакцию зрителей. Он всегда в русле не только художественных течений, но и общественных проблем, культурной политики государства, субъекта федерации, городских властей. Зачастую суждение сценографа об удаче или неудаче постановки точнее мнения критика-профессионала.

Сравнительно недавно устоявшаяся искусствоведческая терминология - что, собственно, представляет собой специальность сценографа - свидетельство сущностных изменений в сфере искусства театра в наши дни.

Рауза Султанова в своем исследовании рассматривает развитие сценографии татарского театра за весь период его существования, с начала XX века до современности. Это актуальнейшая для искусствознания тема, тем более что у автора нет предшественников, а театральная жизнь Татарстана отличается разнообразием и насыщенностью. Культурные традиции татарского народа уходят в глубь веков, а Казань была и остается культурным центром Поволжья. Автор подчеркивает, что не только в Казани, но и в ряде городов Татарстана появились свои театры, свой зритель.

Монография включает приложение, имеющее большую документальную и художественную ценность.

Структуру книги отличает логика, продуманность и своеобразие. Р. Р. Султанова сочетает в своем исследовании культурноисторический подход, обосновывая периодизацию, и собственно искусствоведческий - при анализе произведений художников театра. Теоретически значимы выводы автора о семантике национального мировосприятия, воплотившегося в искусстве.

Отметим кропотливую и тщательную работу Р. Р. Султановой по сбору и атрибутированию материалов исследования. Источниками явились материалы государственных и частных архивов, газетно-журнальные публикации, записи бесед с театральными деятелями. Иссле- дуя сценографию, она взяла на себя дополнительную функцию разыскания, а нередко спасения театральных костюмов. Она собрала и систематизировала уникальные по красоте и оригинальности шрифтовой графики афиши спектаклей. Таким образом, комплексный подход, примененный в исследовании Р. Р. Султановой, очень значим для полноты восприятия смысла деятельности театральных художников, атмосферы театральной жизни, для понимания значения, которое имел театр в культуре татарского народа. Уже при своем становлении татарский театр был подлинно народным. Сами обстоятельства его появления очень живо воссозданы.

Публика не только всегда заполняла зал первой передвижной театральной труппы «Сайяр» (1906-1912 гг.), зачастую необходимый реквизит и костюмы давали именно зрители. Демократизм театра обусловил диалогическую связь со зрителем, ставшую отличительной чертой татарского театра. У его истоков стоял выдающийся писатель-просветитель Г. Камал, чье имя театр носит ныне.

Стиль театрально-декорационного решения спектаклей этого периода автор характеризует как бытовой натурализм с чертами этнографизма. В таком театре, как отмечено автором, преобладающее значение имела игра актеров. Именно с приходом в театр в условиях его стационарной работы художника С. Яхшибаева, приглашенного Г. Камалом, статичность «интерьерного» театра преодолевается. Декорации воссоздают теперь определенное место действия, эмоциональное настроение усиливает цвет и специальное освещение, дополнительно введенные художником. В расширении художественных средств оформления автор видит определенное влияние русского театра.

Вполне объективно выделение Р. Р. Султановой послереволюционного пятнадцатилетия в особую главу. Казань в эти годы - крупнейший центр творческого эксперимента, выставочно-музейной деятельности, художественного образования во всей России. До недавнего времени актуальны были споры о значении творческого наследия казанского ЛЕФа и его татарской секции СУЛФ. В театральнодекорационном искусстве рассматриваемого периода, как показала Р. Р. Султанова, воплощены все художественные направления тех лет - от реализма до ЛЕФа. Отметим, что диссертант последовательно доказывает, насколько 
востребованы оказались достижения «левых» художников на протяжении всего XX столетия. Ценно, что Р. Р. Султанова прослеживает преемственную связь между графическим коллективом «Всадник», АРХУМАСом и Конструктивно-экспериментальной мастерской современного театра (КЭМСТ). Формы агитационномассового искусства в сценическом решении спектаклей этого театра имели конструктивистскую очерченность. Пространство сцены могло преобразиться в разноуровневые площадки, а костюмы и пластика актеров приобрели заостренно-графические формы. Удачным примером постановки КЭМСТ стала «Мистерия-буфф» В. Маяковского, творчество которого вдохновляло многих лефовцев. Автор вводит в научный оборот и рассматривает ряд спектаклей КЭМСТ, особенности их сценографии. Так, успешным было сотрудничество художника К. Чеботарева и молодого режиссера Р. Ишмуратова.

Заметный вклад в театральнодекорационное искусство внес живописец старшего поколения П. П. Беньков (1872-1949). Он был первым профессиональным художником татарского театра. В его творчестве, как считает автор, соединились традиции МХАТа, с тяготением к живописности декораций, и национальное начало - декоративность, праздничность и яркость цвета, стремление к зрелищности спектакля. И это в полной мере проявилось в постановках национальной драматургии - романтической трагедии Ф. Бурнаша «Тахир и Зухра» (1921), а также других драматических произведений, таких как «Заблудшая девушка» (1927), «Хусаин Мирза» (1927) Ф. Бурнаша, «За стенами старой Казани» М. Заитова.

Классик татарского искусства Б. Урманче (1897-1990) тоже отдал должное работе в театре на заре своей деятельности.

Наиболее сложными для татарского театра стали 1930-50-е годы, когда главным критерием искусства становится партийность, а значит - социалистическое содержание. Национальная форма при этом воспринималась как нечто второстепенное. Не будем забывать, что одной из главных задач культурной революции была борьба с религиозными воззрениями и традициями, будь то ислам, христианство или язычество. Искоренению подвергались народные традиции и обряды, сложившиеся веками и составлявшие основу повседневной и праздничной жизни. А значит, содержание фольклорных и литературных произведений подвергалось беспощадной редукции. В сложившейся ситуации ведущее место занимали героикореволюционнные спектакли о преобразовании повседневной жизни.

Судьба произведений и их авторов, как это показала Султанова на примере художника Татарского академического театра М. Абдуллина, часто находилась в руках малообразованных чиновников из числа администрации и партийного руководства. Наиболее неблагоприятным стал период с 1936 по 1945 год, когда репрессиям подверглись видные деятели национальной культуры, а цензура была весьма жесткой. Был репрессирован и расстрелян один из основоположников татарского театра К. Тинчурин, на долгие десятилетия сослан Б. Урманче. Даже после его возвращения в Казань в 1958 году власти продолжали очень настороженно относиться к его работе в театре, и в результате он сделал гораздо меньше, чем хотелось бы. В добровольно-принудительном порядке покинул Казань Беньков, продолжавший работать в Узбекистане, а в Средней Азии с 1941 по 1958 годы жил Б. Урманче.

Чудеса творческой выдумки и изобретательности проявил в то время П. Т. Сперанский (1891-1969), принадлежавший к старой казанской школе. С 1924 по 1969 год он был главным художником Казанского большого драматического театра, впоследствии Татарского академического театра, почти четверть века прослужил главным художником Татарского театра оперы и балета им. М. Джалиля. Автор подчеркивает, что, при всей неудержимой фантазии и стремлении сделать спектакль зрелищным, Сперанский с тщательностью ученого изучал татарское народное искусство и в музейных собраниях, и в экспедициях. Поэтому в постановках произведений национальной классики (Г. Камала, Т. Гиззата, Н. Исанбета) он был документально точен, создавая костюмы персонажей, прекрасно знал интерьер татарского дома. Его сценографию в спектаклях по мотивам общетюркского эпоса «Идегей» и пьесе «Ходжа Насретдин» отличает, как пишет Р. Р. Султанова, индивидуальное восприятие художественного наследия. За время своей деятельности П. Сперанский создал сценографию 63 спектаклей, оставаясь тонким стилистом, знатоком культуры и искусства разных эпох и народов. Следует отметить, что он заимствовал многое из разных источников. Так, колорит его пейзажных задников напоминал мирискусниче- 
скую живопись, произведения Головина и Бенуа. Спектакли по революционной тематике решались с учетом опыта КЭМСТа. Сперанский проявил себя и как выдающийся театральный деятель. В 1952 году на Конференции театральных художников ТАССР он назвал причины кризиса театрального искусства в республике. Это, как отметил художник, проблемы планово-хозяйственного характера и состояние критики, что вело к снижению идейнохудожественного качества спектаклей. Существенно, что изменить качество спектаклей было решено с помощью приглашенных режиссеров. Автор дает высокую оценку результатам сотрудничества режиссера В. Бебутова и П. Сперанского над постановками русской и европейской классики. Успешно был показан в Москве «Король Лир», интерпретированный не столько как произведение реалистическое, сколько как произведение, соединившее черты модерна и средневековой эстетики. Неожиданное прочтение знаменитой трагедии вызвало оживленную полемику в прессе.

Новаторские решения далеко не сразу пробили дорогу в татарском театре. Пресловутый социальный заказ на десятилетия тормозил творческие поиски. Р. Р. Султанова стремится поэтому показать становление собственно сценографии как результата взаимодействия режиссера и художника. О новой функции художника как соавтора спектакля стало можно говорить в 1960-70-е годы, и, как следует из логики изложения, наиболее последовательно двигался в этом направлении П. Сперанский. Обновителем татарского театра, создавшим условно-метафорический, игровой театр, назван в диссертации М. Салимжанов (1936-2002), главный режиссер ТГАТ им. Г. Камала. Предметно-пространственная среда приобретает в постановках режиссера символический смысл. Поиски Салимжанова происходят в русле обновления российского театра в Москве и Ленинграде / Петербурге. Речь идет о творческих поисках Д. Боровского и Э. Кочергина. Актеры в ТГАТ к тому времени являлись в основном выпускниками столичных вузов. Салимжанову не раз приходилось отстаивать свое видение драматургического материала перед театральной администрацией и критикой. Режиссер не боялся обращаться к остросоциальной проблематике.

Впечатляет в книге развернутый эпизод с подготовкой спектакля «Три аршина земли» по повести А. Гилязова. Запрет показа готового спектакля в 1974 году был тяжелым испытанием для театра. Но этот спектакль смогли возродить в 1987 году. Автор отмечает, что пьеса стала визитной карточкой театра на гастролях в 1989 году в Ленинграде. В это время преобладающее значение в репертуаре театров, как и в творчестве писателей и художников, начинают занимать произведения о современности, постановки о революционных преобразованиях в стране уступают место историческим. Происходят глубинные сдвиги в самом национальном сознании, которые говорят о стремлении народа к этнокультурной самоидентификации, к обретению своих корней. Отчетливо проявляется тяготение к героико-эпическим жанрам фольклора. Специалисты все чаще оглядываются на достижения татарского искусства 1920-х годов, явно стремление протянуть связь между эпохами 1920-х и 1970-х годов. Отметим, что, изучая этнокультурные процессы, происходившие в самосознании народов России в конце 1970-х годов, известный этнограф нашей страны К. Чистов делает вывод о «перемещении этнического из области материальной культуры, обрядовой жизни и даже в какой-то мере языка в сферы национальной профессиональной культуры, этнопсихологии и в известной степени фольклора» [Чистов]. Реконструкция аксиологических аспектов сознания происходила с разной степенью интенсивности в различных сфеpax творчества. Театр с его активной позицией и непосредственной связью со зрителем стал ярким выразителем изменившихся ценностей.

Автор избегает в своем исследовании обширного историко-культурного ввода в эту проблему. Для нее, исследователя сценографии национального театра, симптоматично, что в русле культурной политики 1980-х годов в ТАССР запретам и гонениям подверглись издания на татарском языке, сократилось количество изданий и татарских школ, и, как следствие, могла возникнуть проблема потери зрителя. Она обращается непосредственно к репертуару ТГАТа им. Камала и, анализируя этот материал, пишет о сохранении этнокультурной идентичности в 1960-90-е годы. И если излюбленная зрителем музыкальная мелодрама К. Тинчурина «Голубая шаль» с ее замечательными женскими характерами и неповторимыми сценами национального быта входит в обновленный репертуар как классика татарского театра, то в спектакле «Идегей» режиссер М. Салимжанов (сценограф Т. Еникеев) дает героическому дастану новое толкование. Его события 
осмыслены как некий катаклизм, значение которого выходит далеко за рамки феодальной распри. Декорации воссоздают именно такое беспредельное пространство развернувшейся некогда трагедии. Этот спектакль стал одним из свидетельств понимания значимости татарского культурного достояния как составляющего евразийской культуры. Характерным примером творчества сценографа, работавшего в национальном театре не будучи татарином, не связанного с собственно казанской традицией, является деятельность С. Скоморохова, который сумел применить опыт, наработанный в других театрах поволжских городов, чтобы связь между режиссером, сценографом и актерами стала ближе. Автор отмечает, что Скоморохов свободно чувствует себя как сценограф пьес европейских авторов и татарской театральной классики. Понимание особенностей стилистики татарского театра помогло Скоморохову, как считает исследователь, создать спектакли, обладавшие стилевой цельностью. Вместе с режиссером сценограф был готов идти на самый смелый эксперимент даже в отношении национальной классики. Так, были переставлены смысловые акценты в знаменитом «Шурале» Г. Тукая. Лесная нечисть преобразилась в бродящих по чаще интеллектуалов дореволюционного времени, одетых в изысканные белые костюмы. Вполне определенно татарский театр развивался в русле постмодернистских исканий. Завершающая глава монографии - «Многообразие художественного языка сценография 1990-2010 годов». Автор пишет, что в этот период возникает новая, действенная сценография, когда «<..> пространственная среда определяет взаимодействие между всеми компонентами театрального действа» (с. 458). Это действо может обескуражить соцартовским постмодернистским подходом к реалиям современности, как это произошло, например, со спектаклем «Дивана» («Одержимый») Т. Миннуллина (режиссер Ф. Бикчантаев, сценограф Т. Еникеев). Поведение главного персонажа пьесы Виля, во всем подражающего вождю мировой революции, на грани абсурда, и это в современной действительности. Пародируя не вполне адекватное поведение главного героя, сценограф повторяет в реалиях его жизни приметы жизни Ленина: его жилищем становится шалаш, он одет и причесан, как его кумир. Таким образом, деконструкции подвергается советский миф о великом вожде, а вслед за ним и миф о светлом пути, как это произош- ло в спектакле «Баскетболист» (2001). Сценограф организует гротескное пространство, гротескны спортивная площадка, костюмы и пластика самих персонажей, уверовавших в то, что, достигнув невиданных успехов в спорте, они изменят окружающую жизнь в целом.

Смешение жанров и стремление к яркой зрелищности и развлекательности спектаклей проявились в заимствовании театром средств массовой культуры, чье влияние в современных условиях, как считает автор, неизбежно. Добавим, что здесь сказывается заинтересованность театра в молодежной аудитории. В этом контексте значимы и очень важны выводы Р. Р. Султановой о сохранении и преобразовании традиций ориентализма в современном татарском театре. Уже при своем появлении он тяготел к яркости и декоративности, проявлявшейся в костюмах персонажей, особенностях утвари, к использованию декоративных драпировок в решении пространственных зон сцены. Вполне актуальной оказалась тенденция к карнавализации, преображениям, переряживанию персонажей, свойственная драматургии Г. Камала, одного из основоположников татарского театра. Р. Р. Султанова делает вывод, что в разные периоды развития татарского театра мог преобладать либо интерьерный, либо карнавальноигровой тип сценографии. Очевидно проявлено в каждом виде сценографии архетипически свойственное национальному пластическому мышлению освоение мира, подобное ощупыванию пальцами руки. Только центрируется пространство несколько иначе. Оно предметно очерчено в интерьерном типе и вариабельно при карнавально-игровом типе (с. 386). Здесь автор разделяет мысли философа Е. В. Синцова о природе неизобразительного в искусстве ислама. Образно-смысловая традиция искусства ислама наследуется в сценографии ТГАТа в символике голубого, зеленого, белого цветов как доминирующих в кульминационных сценах. Эти цвета могут преобладать в одежде актеров, в драпировках и в оформлении кулис. Так, белый господствует в сценах ритуальных действий. В сценографии спектаклей, относящихся к национальной классике, можно проследить влияние персидской миниатюры с ее праздничностью и цветовой изысканностью, с мотивом райского сада, многоцветием одежд и двухмерностью пространства. Успешным был спектакль по пьесе Назыма Хикмета «Легенда о любви», инсценировки которого прошли во многих странах мира. Очевидно, что в наши 
дни проблема влияния ислама как веры, мироощущения продолжает оставаться значимой для искусства Татарстана и еще ждет своей всесторонней проработки.

Обращаясь к теме зарубежной драматургии в татарском театре, Р. Р. Султанова довольно подробно характеризует специфику восприятия пьес Б. Брехта. Сравнивая постановки в русском и татарском театрах, она констатирует, что «освоение брехтовского наследия русскими и татарскими театрами происходило поразному: в постановках русского театра театральная эстетика немецкого драматурга ассоциируется с системным обновлением принципов театрального искусства. Это прорыв в будущее, отказ от ставших привычными традиций психологического театра. В этом плане путь русского театра совпадает с общемировой тенденцией. А в татарском театре Брехт воспринимается как часть культурного пространства, элементы которого могут быть введены в спектакль, в целом ориентированный на уже существующую традицию. Эти новые элементы брехтовской системы призваны лишь дополнить, обогатить, несколько видоизменить то, что уже накоплено и закреплено в театральном сознании. В этом случае новации Брехта атрибутируются через хорошо узнаваемое - через эпический дух, который всегда был присущ татарской культуре, татарскому словесному творчеству, особенно в его древних формах (сказаниях, легендах, баитах и др.). Эпос всегда был частью театральной культуры татар, поэтому брехтовское наследие в этом контексте предстает не как „чужое“ и радикально новое. Оно согласуется с древней традицией, выглядит как ее продолжение..., поэтому постановки брехтовских пьес на татарской сцене не предполагают отказа от традиций психологической драматургии, рождая очень любопытный и не предполагаемый самим Брехтом сплав двух противоположных линий мировой драматургии» (с. 514).

В репертуаре ТГАТа на рубеже XX-XIX столетий были пьесы Кальдерона, Мольера, Шекспира. Успех этих спектаклей - во многом результат нового качества совместной работы режиссера, актеров и сценографа, выросшего уровня зрительской аудитории.

В Выводах приводятся краткие результаты исследования. Библиография отличается практически исчерпывающей полнотой по истории и теоретическим аспектам заявленной проблематики. Практическое применение результатов исследования и материалов Приложений может быть очень многообразным и при изучении истории искусств, и для теории и практики театроведения, и в музейном деле для создания Музея театра в Республике Татарстан, экспозиции которого могут быть интересными для разных категорий посетителей.

\section{Литература}

Чистов К. В. Традиционные и вторичные формы культуры // Расы и народы: Современные этнические и расовые проблемы/ АН СССР. Ин-т этнографии им. Н. Н. Миклухо-Маклая. М., 1975. Вып.5 С. 32-41.

\title{
ТАТАРСТАН ТЕАТР ЭНЦИКЛОПЕДИЯСЕН ТӨЗУДӘ МӨһИМ ХЕЗМӘТ
}

\author{
Наталья Абрамовна Розенберг, \\ Россия, 18811, Выборг ш., Парковая ур., 2 нче йорт, \\ nat-rozenberg@yandex.ru.
}

\begin{abstract}
Автор Солтанованың татар театры сценографиясен төрле яктан (мәдәни-тарихи, сәнгать) якын килеп анализлавын, күп төрле чыганакларны куллануын, фактик материалны системалаштыруда жентекле эш башкаруын билгеләп үтә. Монографиядә сценография эзләнүләр, катлаулылыгы, каршылыкларының кискенлеге һәм идеяләр көрәше белән уникаль булган чорда театрны яңарту өчен көрәш тарихы буларак тәкъдим ителә. Рецензиядә татар театры сценографиясенең милли үзенчәлеге турында тикшеренү нәтижәләренең әһәмияте ассызыклана.
\end{abstract}

Төп төшенчәләр: татар театры, сценография, милли үзенчәлек, этнокультура процесслары, ориентализм, карнавализация. 